\title{
The Effect of Internal and External Determinants of Electricity Projects in Libya
}

Khulod Elsahati, Edward Godfrey Ochieng, Tarila Zuofa, Ximing Ruan, Bekithemba Mpofu

\begin{abstract}
Among the global energy challenges are securing a sufficient energy supply to meet growing user demands and the provision of accessible energy services. As established from the reviewed literature, electricity is one of the most essential sources of energy. The importance stems from the role of electric power in fulfilling the main consumption needs for basic energy as one of the inputs to the production process. To date, the focus of research in the field of the demand for electricity has been mainly on developed economies. Adding to the few studies carried out in developing economies, this study examined the issue in the Libyan context. This paper utilised data from semi-structured interviews with twenty senior practitioners within the Libyan electricity sector. From the findings, it was found that electricity demand, political factors, recession, oil prices are among the major determinants of electricity projects in Libya.
\end{abstract}

Keywords: Libya, Internal determinants, External determinants, Libya electric projects, Libya electric sector.

\section{Introduction}

Libya is an important country in the Middle East and North Africa (MENA) region because it occupies a strategic location that links Southern Europe with West and Eastern Africa (Bhattacharyya and Blake 2009; Daft and Marcic, 2013; World atlas, 2014). Accurate forecast of electricity demand is very important for a country such as Libya because its electricity demands need to be met in real time. In addition, electricity suppliers should not rely on records of stored electricity as safeguards between the fluctuating electricity demand and supply. In reviewing the literature, no detailed studies were found on the effects of internal and external determinants of electricity projects in Libya (Bureau of Energy Data and Studies, 2004; Mason 
and Kumetat 2011). As such it was important to establish how the price, income, population, temperature and appliance imports have affected the demand for electricity in Libya. Precise and robust estimation of electricity demand is crucial due to the fact that overestimation of demand may lead to the government making unnecessarily large investments in electricity generation and transmission assets. This may burden the economy financially, due to the fact that Libya is a country which is developing and, as such, still struggling politically and economically. Moreover, underestimation of electricity demand may lead to future shortages of electricity which may prove disastrous for the economy (Enerdata, 2013; Mbendi, 2005; Siddiqi and Anadon 2011). For this reason, it was vital to propose a sustainable framework that could be used by policy makers to address energy demand issues in Libya.

It is worth highlighting that recent developments in Libya have heightened the need of a balanced energy mix policy. The Libyan government is currently facing an energy shortage caused by the continued political fracture, growing militancy and minimal governance (Bureau of Energy Data and Studies, 2004; Enerdata, 2013; Energy Department, 2013; Mbendi, 2005). As established from the reviewed literature, electricity is an essential element of the Libyan economy (Barros et al., 2011; Bhattacharyya and Blake 2010; U.S. Energy Information Administration, 2013). In recent times, electricity as one of the most important energy sources has witnessed considerable decreases in consumption figures. These cutbacks have been mainly due to the growing increasing living standards, minimal governance and political fracture. Thus, this paper appraised the supply of electricity side in an attempt to propose a sustainable electricity framework. There is a review of policy issues and energy projects in Libya. After this introduction, a review of pertinent literature is undertaken. The review covers policy issues affecting energy projects in Libya; it also discusses the role of energy sources in the Libyan economy as well as the development of electric power in Libya. This is followed by an 
explanation of the method used for data collection. Subsequently, the main results and proposed framework are discussed. The finally section summarises the paper and suggest several courses of action for the Libyan government.

\section{Policy issues relating to energy projects in Libya}

Anticipations of Libya's economic advisers concerned with all energy producing utilities are that the country would recover the non-renewable energy through the implementation of eco-friendly energy production policies. For example, they derived an understanding that the country's crude reserves were instrumental in reshaping the country's energy demand levels through an increase in the usage of renewable energy sources. The country's energy production rates were influential towards increments in gross domestic product (GDP) and Gross National Product (GNP) as Libya ranked the tenth global producer of energy in 2008 (Daft and Marcic, 2013). Increased demands of the scarce product of the economy led to the intensified exploration of oil. The main importers of the country's oil were Italy, China, Yemen, Sudan, U.S and Egypt amongst other African economies. Libya's exportation of oil grew autonomously as the global fuel prices escalated profusely (World Bank, 2012).

Currently, energy in the country is implicit to economic growth rates since its oil exports meet 78 per cent of the European energy demands (Economic and Social Commission for Western Asia, 2007). Libya increased its domestic consumption levels of renewable energy and increased exportation of non-renewable energy in the context of crude oil and natural gas. These practices reflected increments of 1.7 per cent and 2.1 per cent respectively from 2008 to the first quarter of 2013 (Economic and Social Commission for Western Asia, 2007). These energy consumption and production affected the country's energy capacity of production and the overall production (Economic and Social Commission for Western Asia, 2007). Furthermore, the country's economic welfare improved despite its tenth position in energy production. The significance of 
energy in an economy such as Libya is the ideology of enhanced economic production as the earnings from the exports are likely to be spent on projects that would lead to enhanced economic progression (World Bank, 2012).

\section{An overview of electrical projects in Libya}

The electrical system in Libya is run by the General Electric Company of Libya (GECOL), owned by the state, which is responsible for generation transmission and distribution of electricity, throughout the country (Elabbar 2008). The state-owned company is responsible for desalination of water plants in Libya. However, due to the projected high increase in demand for electricity throughout Libya the government undertook several initiatives aimed at increasing the supply of electricity to the national grid. Elabbar (2008) revealed that the transitional government of Libya was on course to ensure that radical restructuring of the Electricity Ministry and GECOL was done, and projects, which had been initiated by the former president Muammar Gaddafi's regime, were revived to enable the country to meet the ever increasing demand for electricity. Work begun in 2012 to expand and refurbish national generation capacity and transmission infrastructure destroyed by forces loyal to former president Muammar Gaddafi (Energy Market, 2012).

In addition, since 2005 several electrification projects have been ongoing. The aim has been to improve the electricity distribution networks to meet the rising demand for power. One such was witnessed when GECOL awarded Siemens a contract for the supply of $220 \mathrm{kv}$ and 33/11 kv substations (Ramelli 2006). It is also reported that three $400 \mathrm{kv}$ substations together with the 250 MW gas turbines delivered to Zwitina Misrata and Bengazi power plants have already been successfully commissioned. According to GECOL this will add more than 1,500 MW of power to the country's national grid (Ramelli 2006). Another five $400 \mathrm{kv}$ substations were to be constructed and commissioned by 2012. In total, GECOL projected its expansion program 
would help add more than 6300 MW during the period 2006-2012 (Ramelli, 2006). Table 1 summarises a few power generation projects which were scheduled for execution between 2004-2010. The table highlights the present situation of the selected projects as well as the projected capacities.

Table 1: Generation power projects scheduled during the period (2004-2010)

\begin{tabular}{|c|c|c|c|}
\hline Name of power plant & $\begin{array}{c}\text { Installed Capacity } \\
\text { (MW) }\end{array}$ & $\begin{array}{c}\text { Expected execution } \\
\text { period }\end{array}$ & Project present situation \\
\hline W. Mountain P. Plant & 660 & $2005-2007$ & Commercial Operation \\
\hline Tripoli W. Extension I & 650 & $2004-2006$ & Commercial Operation \\
\hline Benghazi N.C.C.P & 750 & $2004-2007$ & Under Contracting \\
\hline Gulf system P. Plant & 1400 & $205-2007$ & Commercial Operation \\
\hline Zawia C.C.P. Plant & 1400 & $2007-2012$ & Under Study \\
\hline Musrata Steel P. Plant & 750 & $2008-2012$ & Planned \\
\hline Tripoli W. Extension II & 650 & & 2007 \\
\hline
\end{tabular}

Source: Ramelli 2006

The government of Libya having signed the Kyoto Protocol of 2005 is also engaged in the development of environmentally friendly sources of energy (Brand 2013; Ekhlat et al., 2007) and one of such is the solar energy. This is supported by the fact that Libya is a very hot country with more than 88 per cent of its land surface considered desert. Therefore, it makes it a better country to use solar energy to help match the ever increasing demand for electricity. As a result, the government of Libya is encouraging its citizens to buy the solar panels sold by the government at subsidised prices (Ekhlat et al., 2007; Omran 1993; Shah 1996). This initiative has helped inject more than 140,000 TWh/y (Terawatt hour/year) and has seen many rural areas that are not supplied with the national power grid due to population and need concerns (Ekhlat et al., 2007). Research carried out shows that Libya has immense potential for 
producing wind energy (Energy Market, 2012). This is in line with the government's orientation toward green energy. The government has identified several sites with high potential of tapping wind energy to help meet the ever increasing demand for electricity in the country. The areas having been acknowledged include Misratah, Dernah, Sirt, Tolmetha, and Al Maqrun (Ekhlat et al., 2007).

\section{The role of energy sources in the Libyan economy}

Gelvin (2013) suggested that Libya has undergone rapid social and economic restructuring, which has been apparent in the recent uprisings and revolutions in the wider Arab world in the past decade. According to Sehib et al. (2013), the trend more recently has been for the Libyan government to also encourage private sector investment and attract foreign capital. However, historical data from the Ministry of Planning and Development still indicate that the Libyan economy suffered during the period of the fifties from backwardness and disability. Poverty and unemployment were the most important attributes and features of that period, but the economic and social situation of the country soon changed following the discovery of oil in commercial quantities after 1959 and the start of exports at the beginning of the sixties (Darbouche and Fattough 2010; General People's Committee for Planning, 1998; Guenos 1999). Thus, the Libya economy changed during the sixties from a backward economy dependent on agriculture to a development economy (General People's Committee for Planning, 1998). The period saw a significant increase in the average per capita income, providing sufficient capital to finance development projects to build economic and social sectors (Ministry of Planning and Development, 1962). Table 2 illustrates the evolution of real GDP in different economic sectors during the period (1962-2010) at constant prices of 1997. 
Table 2: Evolution of real Gross Domestic Product GDP during the period (1962-2002) at constant prices of 1997: Libyan Dinar LD Million

\begin{tabular}{|c|c|c|c|c|c|c|c|c|c|c|}
\hline Year & $\begin{array}{c}\text { Oil and } \\
\text { gas } \\
\text { sector }\end{array}$ & $\%$ & $\begin{array}{c}\text { Agriculture } \\
\text { sector }\end{array}$ & $\%$ & $\begin{array}{c}\text { Industry } \\
\text { sector }\end{array}$ & $\%$ & $\begin{array}{c}\text { Other } \\
\text { sectors }\end{array}$ & $\%$ & GDP & $\%$ \\
\hline 1962 & 775.5 & 38.4 & 184 & 9.1 & 34.7 & 1.7 & 1025.3 & 50.8 & 2019.5 & 100 \\
\hline 1965 & 4287.3 & 55.6 & 244.7 & 3.2 & 43.2 & 0.5 & 3113.9 & 40.7 & 7689.1 & 100 \\
\hline 1970 & 10834.7 & 58.9 & 183.9 & 1 & 71.6 & 0.4 & 7314.1 & 39.7 & 18404.3 & 100 \\
\hline 1975 & 3994 & 42.2 & 414.5 & 4.4 & 146.3 & 1.5 & 4915 & 51.9 & 9469.8 & 100 \\
\hline 1980 & 4943.7 & 41.6 & 752.9 & 6.3 & 361.4 & 3 & 5813.5 & 49.1 & 11871.5 & 100 \\
\hline 1985 & 3314.8 & 33.5 & 940.1 & 9.5 & 670.4 & 6.8 & 4964 & 50.2 & 9889.3 & 100 \\
\hline 1990 & 4059.8 & 35 & 1136.2 & 9.8 & 802.1 & 6.9 & 5600.9 & 48.3 & 11599 & 100 \\
\hline 1995 & 4465 & 34.1 & 1175.6 & 9 & 905.9 & 6.9 & 6564.4 & 50 & 13110.9 & 100 \\
\hline 2000 & 4255.2 & 29.4 & 1274.6 & 8.8 & 1049.3 & 7.3 & 7872.4 & 54.5 & 14451.5 & 100 \\
\hline 2005 & 6030.6 & 28.2 & 1347.8 & 6.3 & 4732.9 & 22.1 & 9254.5 & 43.3 & 21365.8 & 100 \\
\hline 2010 & 5714.2 & 21.3 & 2011.3 & 7.5 & 3343.1 & 12.5 & 15706.8 & 58.7 & 26775.4 & 100 \\
\hline
\end{tabular}

The table above illustrates the high contribution of the oil and gas sector to GDP during the period of the sixties, and the low contribution of other sectors which characterised this period. As observed in table 2, the dominance of the oil and gas sector, with the percentage of its contribution to GDP to 55.6 per cent in 1965 , increased to 58.9 per cent in 1970 , largely because of the decline in the contribution of the agricultural sector and the industrial sector during this period (Attiga, 1987; Chlebek, 1998). There were several reasons including the failure of these sectors on the one hand and the increasing importance of the oil sector on the other hand, which led to the migration of labour from traditional sectors of agriculture to the oil and gas sector (Attiga, 1987). During the period (1970-1997) development plans and budgets spotted and executed large investments amounted to 36.8 billion dinars (General People's Committee for Planning, 1998). The next section details the research method and symposium of findings drawn from senior practitioners. This is followed by discussion of results and proposed framework. 


\section{Method}

The reviewed literature identified a gap within the previous literature which had not previously been investigated, however in order to carry out the investigation a research strategy had to be formulated. Twenty semi-structured interviews were carried out with managers, engineers and electrical professionals. Prior to the commencement of the main study, a preliminary pilot study was carried out among ten senior practitioners in the General Electric Company of Libya. Of the ten participants, six were senior managers and engineers while the rest were with electrical professionals who had working knowledge of power plants operations in Africa and Middle East. The purpose of the pilot study was to assess clarity of questions, timing and suitability of the respondents for the study, and to establish its reliability and validity. The final interview questions were developed based on feedback from the pilot study. This was considered to be the most effective approach when gathering interview participant's perspectives. The purpose of embarking on semi-structured interviews as part of the study was to:

- Appraise how determinants of electricity demand affect electricity projects in Libya;

- Ascertain the impact of political stability on electricity projects in Libya;

- Identify the effect of economic recession on electricity projects in Libya; and

- Identify the impact of electric projects in Libya.

Semi-structured interviews were chosen so that open-ended questions which were directly linked to identified issues from the literature could be further explored. Using semi-structured interviews had additional benefits for this study because it allowed for an exploration of the actual experiences of participants. It also enabled participants describe in-depth accounts of their personal views and opinions of the Libyan energy sector (Bryman and Bell 2011). This was an essential factor for choosing this method as this meant that further probing could be carried out if the interviewee touched on any aspects which were not part of the outlined plan but could 
be used to further help meet the aim of the study. All interviews were recorded using a digital recording device which allowed the researchers to focus on the interview at hand, whilst ensuring analysis of the qualitative data was upon an accurate record.

According to Creswell (2014) sampling can be defined as a process by which a relatively small number of individuals, objects or events are selected and analysed in order to find out something about the entire population from which the sample was selected. In this study, stratified random sampling was used to select respondents in the three population categories (managers, engineers and electrical professionals), this made all the respondents in the target population to have an equal and unbiased chance of participating in the study, and this was made possible since the sampling frame was available. The respondents were taken from the General Electric Company of Libya (GECOL). It is worth highlighting that this qualitative research achieved an in-depth insight into energy efficiency by interviewing participants with energy efficiency knowledge. Advantageously, each of the participants had been specifically involved in some aspect of most Libyan electricity projects.

NVivo software was best suited for this study. One of the primary functions of this software that emerged was the ability to add memos to sections of the data, as thoughts and connections were made during all phases of the data analysis. It enabled the researchers to sort through the data and at the same time allowed exploration for patterns and recurring phenomena. An appropriate coding system was developed to establish the inter-related themes and statements linked to the overall aim and objectives of the research. The themes selected were based upon those identified in the literature reviewed, in conjunction with specific issues raised during the interview process. In order to validate the results of the study, workshops and group discussions were held with twenty participants in four groups. Each group had five participants who at various times were head managers, managers, technicians, engineers, technicians and other staff members in GECOL. 
These are people who had professional understanding of issues to do with electricity in Libya and were either involved in policy formulation or in the implementation of heavy electric projects. The main purpose of this process was to ensure that the study provided accurate results and performed a better job in tracking electricity consumption in Libya which helps in future decisionmaking. The validation took place after the verification process. This was achieved through focus groups. The main outcome of the validation and verification process was that the proposed framework was found practical and provided a methodology for solutions that can be taken up by the electric sector and for the government to adopt regular mechanisms to deal with the consistent upsurge in the demand and provide the basis for stable supply of electricity. The philosophical consideration of this research can be viewed from two broad perspectives. The first perspective was linked to the essential requirement of investigating internal and external determinants. The second perspective was linked to examining the role of electric power in fulfilling the main consumption needs for basic energy as one of the inputs to the production process.

\section{Findings and discussion}

The findings are presented and discussed below under themes which emerged from the data analysis. Where appropriate descriptive quotes drawn from the interview transcripts have been incorporated to express views of the participants interviewed.

\section{Theme 1: Internal determinants of electricity projects in Libya}

\section{Sub-theme 7.1: Electricity demand effect on the Libya's electricity projects}

Most participants explained that the construction of electricity projects depend on the willingness of the continuous demand for electricity in the country these views are aligned with Halvorsen (1993). Furthermore, an investigation of the internal determinants of electricity projects in Libya showed that the most effective factor was the demand for electricity. Participants agreed that 
the number of projects which are being initiated in Libya have been mainly informed by the increased demand for electricity recorded in the country. Majority of the participants suggested that population factor could be a main determinant of demand. According to a senior manager:

\section{"The population size of the household and the urbanisation have led to a higher supply"}

In Libya both the size and the number of the households plays a very important role with regards to influencing the electricity demand in the country. The household numbers on a higher note affects the total number of the residential customers who are in a position to purchase electricity and also the variations on the size of the households will affect the level and size of usage of electricity. When the numbers of customers are high then it means that the demand for the electricity will be high. High number of the residents will be in a position to demand the electricity. This will lead to an upsurge on the pressure on the supply of electricity and therefore more projects (Berndt, 1991).

As suggested by the twenty participants, population level has a direct influence on electricity production and consumption. Participants further noted that population level affects water consumption especially by tapping water for irrigation and for home consumption. While attempting to establish the influence of population on electricity production and consumption, a senior engineer disclosed that:

"The amount of water usage is often of great concern for electricity generating systems as populations increase and droughts become a concern".

Figures from the encyclopaedia of the nation's indicate that Libya's population of roughly $5,115,450$ has seen a yearly growth rate of approximately 3.5 per cent since 1975 , when it was $2,400,999$ (Encyclopaedia of the Nation's 2014). With a forecasted yearly growth rate of 2.1 per 
cent, the population will reach $7,600,000$ by the end of this year. In 2000 , the birth and death rates were 27.68 births per 1,000 population, and 3.51 deaths per 1,000 populations, respectively (Encyclopaedia of the Nations, 2014).

The residential demand for electricity in the country is presumed to be mainly resulting from various exercises of choice whereby the consumer maximises the welfare which is subjected to the budget constraint. The demand for electricity by the consumer is believed to be a function of price complements like natural gas and the consumer choice. It is worth noting that electricity does not convey any benefit to the consumer. According to Berndt (1991) consumers in most cases will gain from the services of the appliances which mainly require electricity. The services include cooking, refrigeration, air conditioning, drying and washing clothes among other numerous services. For commercial and other industrial activities electricity is a major factor of production which is inclusive of the inputs.

Halvorsen (1993) suggested that the presented demand for electricity is believed to be resulting from a number of decisions which are taken by the producer when it comes to the maximisation of profits. For the producer who is interested in maximising profit, the price of any related product includes electricity. Their demand for electricity is also influenced by other factors which include water and weather condition in a country. The existing demand for electricity projects in the country depends on the number of consumers who are in need of electricity, the level and type of goods which are being produced in the country. The demand for the residential is forecasted per individual's households and industrial basis.

\section{Sub-theme 7.2: The effects of political factors on Libya's electricity projects}

During the interviews, participants noted that the government of any state has a political impact on the different sectors of the state, as well as on international relations. According to Momoh 
and Milli (2010), internal conflicts or external conflicts with other countries neglected from access to development funds could affect electricity development projects. Most participants affirmed that internal and external Libyan practices and policies played a role in electricity projects in Libya. They suggested that external political conflicts have resulted to no limited development. As observed during the fieldwork, certain parts of the country (especially rural areas) have no supply of electricity. Participants discussed that the lack of electricity in these rural areas has resulted to lack of improvement and making the country to lag behind economically. One senior manager stated that:

"Internal Libyan practices and policies were affecting development projects in Libya, particularly in the awarding of contracts to foreign countries for the construction of electricity generation plants. Policies and procedures of Gaddafi's rule were responsible for unwillingness of foreign investors to construct more electricity projects in Libya over the period 1980-2010".

Radicalism was further extended to the economy by the president, with the Libyan leader adopting awkward ideological thinking that are not necessary for faster economic growth such as socialism, Arab nationalism and populism (Lochner and Dieckhiner 2012; Zoubir 1999). While executing these ideologies, Gaddafi outlawed the ownership of private property and demanded for the elimination of private savings. Such radical ideological reforms had disastrous effects on the construction of electricity projects by private firms (Zoubir, 1999).

During the US and UN unilateral sanctions, investors shunned away from investing into Libya's oil resources. As suggested by participants, during this time, electricity projects that were being constructed by foreign countries had to be stopped. The electricity projects could only be completed after the UN sanctions on Libya had been removed in 1999. The Libyan economy 
and other electric projects weakened at about the same time president Reagan's administration imposed trade sanctions on Libya (O'Sullivan, 2003).

It is worth mentioning that major environmental issues and international environmental agreements like natural fresh water resources, desertification, and the Great Manmade River Project have hampered Libya's electricity projects (USA 2007). The manmade river project will be biggest water development system in the universe and it is being constructed to convey water from the large Sahara aquifers to the coastal cities. The major international environmental agreements include Conventions on Desertification, Marine Dumping, Nuclear Test Ban and Ozone Layer Protection. Libya has signed and ratified these agreements. Agreements signed but not ratified by Libya include Biodiversity, Climate Change and Law of the Sea (USA, 2007).

\section{Sub-theme 7.3: Electricity tariff effect on the Libya's electricity projects}

From the results, another important factor identified was the electricity tariff. One participant explained:

"Prices of electricity remained stationary for long periods from 1980 to 1995 , then the prices changed in accordance with the Resolution No. 93 for the year 1995 and these prices are still fixed."

This means that real electricity prices tend to decline over time. As the senior engineer noted:

"We are working as a monopoly company supported and protected by the state. The company was established to achieve social and national objectives, such as creating job opportunities for Libyan people and providing the domestic market with goods and services, while profitability was not a priority". 


\section{Theme 2: External determinants of electricity projects in Libya}

During most interviews, participants further enumerated several external determinants of electricity projects. The most common determinants have been outlined and discussed below.

\section{Sub-theme 8.1: Recession}

According to Willis (2011), a recession is a business cycle reduction, which is a common deceleration in economic movement. In case of a recession potential investors will be discouraged from investing in an economy. What this implies is capital intensive projects like electricity projects are not sanctioned. Macroeconomic signs such as GDP, employment, investment spending, capacity utilisation, household income, production profits, and inflation fall, whereas bankruptcies and the unemployment rate increase. Recessions normally occur when there is a prevalent fall in spending (an adverse demand shock). Recession can be triggered by different events, such as a financial crisis, an external trade shock, an unfavourable supply shock or the bursting of an economic bubble. Governments use expansionary macroeconomic policies, such as increasing money supply, increasing government spending and decreasing taxation during a recession (Biresselioglu et al., 2012; Espey and Espey 2004; Willis, 2011).

Several factors explain the recent trends in investment especially in electricity projects. Privatesector firms were deeply affected by the Asian and subsequent Latin American financial crises (Firebaugh 1992; Ghosh 2009). The Enron collapse and its aftershocks also featured prominently in influencing American and European-based firms to reduce risk exposure in emerging and developing-country markets and refocus on core activities at home (Coudouel et al., 2006). Furthermore, DFls began to reconsider their position of restricted infrastructure investment, which had predominated throughout the 1990s. As concessionary funding became available again, many countries opted for publicly funded projects, rather than their private 
sector counterpart; for instance, Egypt has seen its current five-year power investment implemented by the incumbent, state-owned utility, and supported entirely by concessionary loans (Greene 2008).

The majority mainstream economists trust that recessions are caused by insufficient aggregate demand in the economy, and support the use of the expansionary macroeconomic policy in recession period (Coudouel et al., 2006; Momoh and Milli, 2010; Marktanner and Salman 2011; Singh 2010; Willis, 2011). Strategies favoured for moving an economy out of a recession differ depending on the economic school followed by policymakers. Monetarists would support the use of expansionary monetary policy, whereas Keynesian economists may support increased government spending to promote economic progress. Supply-side economists can propose tax cuts to endorse business capital investment. Once interest rates fall to zero conventional monetary policy cannot be used and government should use other measures to encourage revitalization (Coudouel et al., 2006). Participants were asked to indicate the recession effect on the Libya's electricity projects. As suggested by the participants, recession has a minor impact on the Libya's electricity projects. Utilising several illustrations, one of the participant noted that:

"Even though the recession might have an impact on the construction of electricity projects in different countries, the Libyan government must not allow this happen in Libya, especially as it is oil country".

As countries restructure their sovereign debts, many are expected to decrease foreign aid and focus on domestic issues first. The protectionist tendencies are common during harsh economic times and countries prefer to look after their own citizens. In 2010, John Clancy, of the European Commission Humanitarian Aid and Development noted, the concern that we hold is 
that not only the EU states but also the broader donor community become very inward-looking, in the sense of their home policy, to an extent understandably, because they now have to deal with the economic impact on various investment projects (Momoh and Milli, 2010).

\section{Sub-theme 8.2: The effects of oil prices in the Libya's electricity projects}

Economists have shown great concern regarding oil prices and they have tried their level best to ensure that prices are stabilised. As the rule of thumb, for every $\$ 10$ increase in price of oil barrel will cause a reduction in the economic growth especially in the gross domestic production by almost 50 per cent within two years. If the price of oil and of paying workers is high these would mean that the cost of producing electricity would be very expensive (Jumbe 2004). Pricing may be made too heavy and influenced by cost. When all the cost that led to production is high the final price is likely to be high. It is worth noting that a good pricing on products is one that benefits the manufacturers and at same time it is favourable to the consumer (Barros et al. 2011; Hope and Morimoto 2004; Willis 2011).

Jumbe (2004) found that a company's costs take two forms; fixed and variable costs. Fixed costs (also known as overhead) are costs that do not vary with production or sales level. Variable costs vary directly with the level of production and variable costs are influenced by fluctuations of prices. In case prices are high during a certain period, this would mean the variable cost is directly influence. To price wisely management needs to know how its cost vary with different level of production for procurement managers, developing variable costs to use in pricing decisions is frequenting a frustrating process.

As mentioned above, this means that if the price of oil and of paying workers is high these would mean that the cost of producing electricity would be very expensive in Libya. In order to 
establish if the changes in oil prices had an impact on the construction of new electricity projects, participants were asked to indicate the extent of importance regarding the oil prices on electricity projects in Libya. As found, opinions of the participants were different; some of them felt that there was an impact of oil prices while others felt that the impact of increasing oil prices and the country's quest for the export of oil were reasons to convert many of the power plants from oil to natural gas in order to reduce costs.

\section{Sub-theme 8.3: Alternative infrastructure development}

According to Al. Azzam, (2002) there are a number of growth variables that are directly related to the cost and availability of electricity. A policy that ensures that the cost of electricity is lowered in the economy will lead to the growth of other infrastructures like schools, hospitals among others. The availability of electricity helps in opening up the economy to a myriad of investors. It ignites the growth of other sectors. Reduced costs of electricity will reduce the costs of living in the economy. When the cost of electricity is high then the cost of production will also be high. Since firms are in business to make profit it is likely that these costs will be transferred to consumers. Cheap costs of electricity will result in the lowering of most of the basic products in the economy. The government of any country must therefore look at all available options to ensure that right policy is adopted. Internal and external factors should be taken into consideration. The costs of constructing major electricity projects should be looked at in comparison to the revenues which are expected to be produced from the viability of a successful project (Publishing and Agency, 2012).

From the above, participants were asked to indicate the effect of development in other infrastructure on the electricity projects in Libya. In addition, the verification results showed that the most effective factor was the improved development of other infrastructure. Participants 
acknowledged that the main driver for the production of electricity is the creation of buildings and expansion of cities. The participants pointed out that in Libya the problem lies in poor planning and administration of the state.

\section{Discussion of results and proposed framework}

The average real price of electricity demand, the real value of the imported electrical appliances, GDP, population, the temperature difference and the lagged electricity demand explicitly showed the variation in electricity demand in Libya. The factors that have led to the current status of electricity supply and demand vary from internal factors (demographic and political factors) to external factors (such as changes in the international politics and global economy). The price elasticity of demand and income elasticity of demand in the long run are greater than elasticities in the short run, implying that these variables have a significant impact in the long term. The average price of electricity and the population are significant determinants of electricity demand. Taking into consideration the impacts of these factors on the demand of electricity in Libya and the projection of future demand, it is imperative that an appropriate electricity framework be developed. The purpose of the proposed electricity framework was to provide the basis for:

- Stable supply of electricity to the citizens and their businesses; and

- $\quad$ Projection of future electricity demand in the country. 
The study results showed that the total electricity production in Libya has increased; however, the results of the study further suggested that there is a significant increase in demand for energy. This has turned out to be more than quantity supplied, where various cities and regions of the country have suffered and continues to suffer from periods of interruptions in electricity supply. In addressing the above, there was a need to propose a framework that would:

- Highlight the demand requirements for electricity in Libya; and

- Establish how electricity organisations can adopt regular mechanisms to deal with the consistent upsurge in the demand.

The study findings indicated that in order to formulate the appropriate integrated framework, it was necessary to consider the factors that affect the demand and supply of electricity in Libya. Figure 1 summarises the main components of the framework that emerged from this study. Firstly, from the aspect of the demand the study found that there was a diverse set of factors that affect electricity demand in Libya. These included the average real price of electricity, the real value of the imported electrical appliances, GDP, population, the temperature difference and the lagged electricity demand. Secondly, from the aspect of electricity supply the study found that there was a diverse set of factors that affect electricity projects in Libya or even the development of existing projects. These factors included electricity demand, political effects, recession, oil prices and improved development of other infrastructure. 


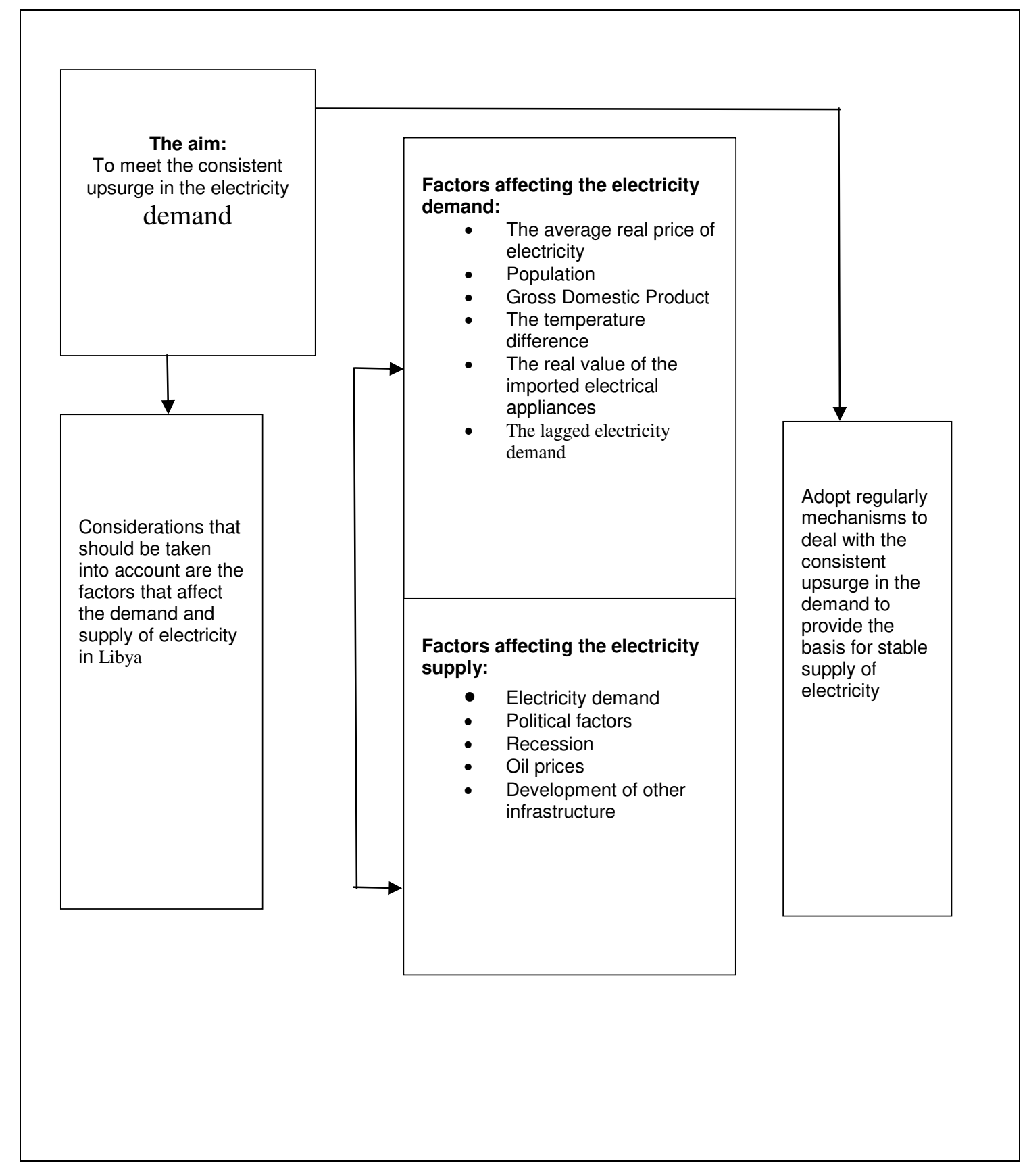

Figure 1: Represents the aspects of the proposed framework

The study showed that the factors affecting the demand have the effect of a double effect on the electricity sector, the first impact on the demand side and the other effect on the supply side of the electricity. The literature supports the view that any policy formulation or electricity 
framework must consider the factors affecting the demand. For instance, Lin (2003) used a macroeconomic approach to develop a long run electricity demand model to analyse the main factors affecting demand for electricity in China (Lin, 2003). Lin (2003) reported a stable and significant relationship among relevant variables after China's economic reforms three decades ago to make all variables more responsive to market forces. Since the reforms were initiated in 1978 , the demand elasticity of GDP was estimated as 0.8 which is lower than the pre-reform period. This implies that Libya can also improve the demand and supply of electricity through structural changes in the economy.

\section{Key implications of the proposed framework}

The issues identified in Figure 1 were exhaustively examined in the validation meetings. There was general consensus that Libya has witnessed a consistent upsurge in the electricity demand over the past three decades, as well as facing frequent interruptions in the power supply during the same period. The participants there acknowledged that was an urgent to improve electricity sector performance. From the findings, participants suggested that the aspects of the proposed framework provide a significant step towards improving the electricity sector performance. From the validation results, it was found that the proposed framework with a number of conditions and initiatives is conducive to providing the basis for stable supply of electricity to the citizens and their businesses, and providing the basis for projection of future electricity demand in the country. The four focus groups believed that the energy sector and the Libyan state should take into account aspects of the proposed framework in order to address the continued escalation of electricity demand in the country. The following are the actions which were proposed:

- Economic planning;

- Socio-economic development policy;

- Development of new power plants and expansion of the existing capacity; and 
- Improved development of other infrastructure.

As a result, participants suggested that the earlier framework be reorganised to reflect these actions as shown in Figure 2.

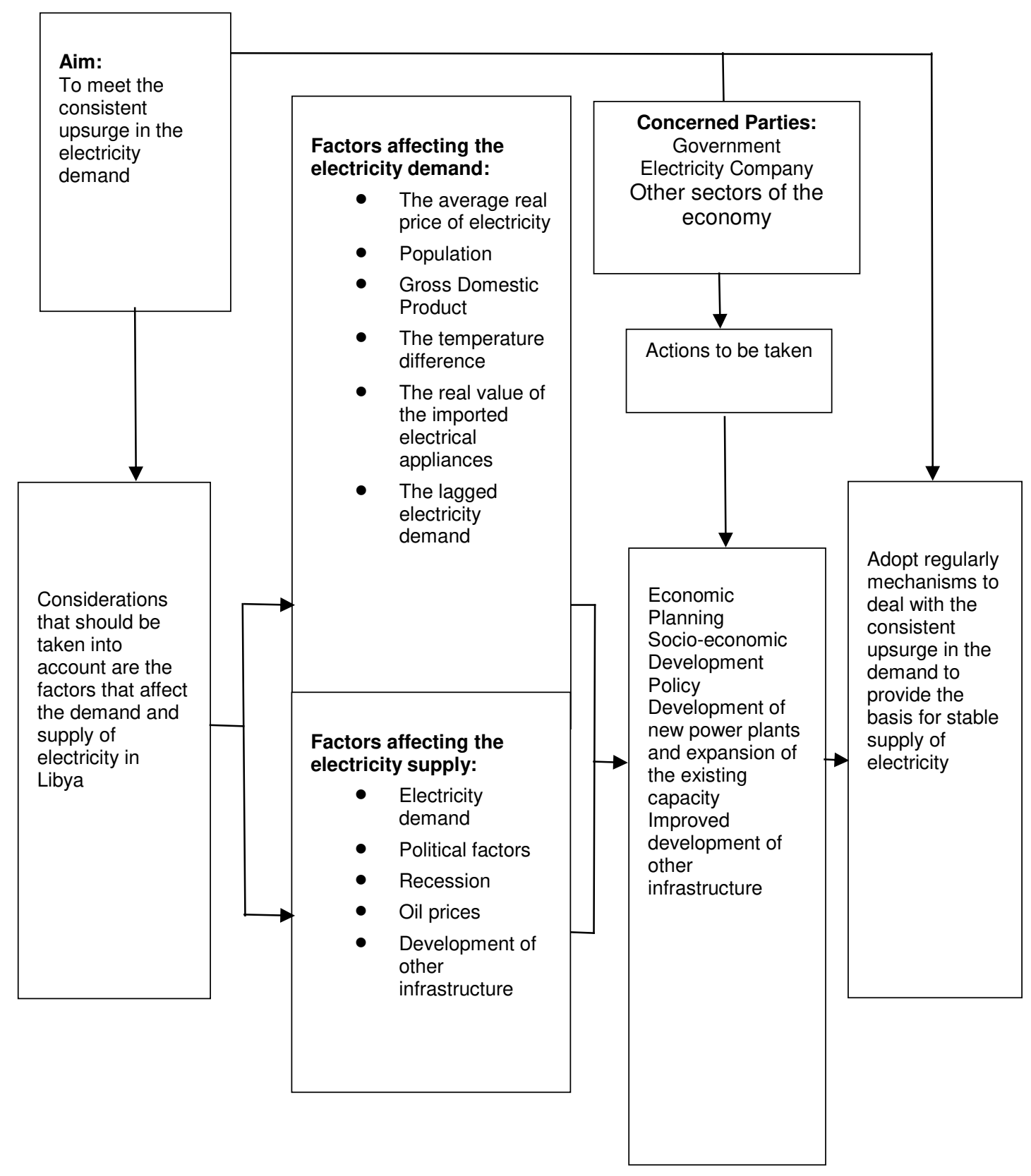


Figure 2: Represents the revised aspects of the proposed framework

Figure 2 represents the revised aspects of the proposed framework. The framework consists of the various influences on electricity demand and the various influences on the electricity supply and parties responsible. The key factors identified to have significant influence on electricity demand are price elasticity, population, income, GDP, and changes in other sectors of the economy. These factors require a sound socio-economic development strategy, pricing strategy, upgrade or development of new power plants, and improvement in other infrastructure projects. Participants agreed that the average real price of electricity, the real value of the imported electrical appliances, GDP, population, the temperature difference and the lagged electricity demand are the main factors that directly affect the electricity demand. The increasing population growth rate and income are the most significant determinants of demand. Despite, the continued improvement of income among the citizens, the residential electricity demand will continue to rise. This is because changes in income will highly influence the amount of electricity people purchase. Any further changes in the income of Libyans will lead to changes in electricity consumption. As suggested by the participants, the increased income will influence the usage. It is worth mentioning that all of the above findings have serious implications on the production and supply of electricity and most notably, policy formulation. The government of Libya and energy organisations need to plan the supply of electricity according to trends in the economy and individual improvement of income of the citizens.

The participants also believed that as the rate of socio-economic development increases, the demand for electricity is expected to rise. Urbanisation, industrialisation, and literacy rates are some of the developments which will exert more demand pressure on the electricity supply. The participants claimed that the government should take into account the urbanisation rates in Libya in the energy policy formulation. Electricity companies can also take a cue from the 
urbanisation trends and other socio-economic developments to plan the delivery of electricity according to the rising demand.

In general, the participants welcomed the proposed framework as a solution to meet the rising demand for electricity. Participants noted that the demand for electricity in Libya has been rising for the past three decades. The import of this fact is that demand will continue to rise as the Libyan becomes more sophisticated. The GDP continues to grow which will put more pressure on energy organisations to produce more electricity to meet the demands of the economy. As the participants indicated, the supply of energy is directly correlated with the country's economy growth. In this regard, the country needs more supply of energy in order to sustain its economic growth. In the context of Libya, this is urgent because there are symptoms of insufficient supply of electricity (for example, electricity rationing). In order to resolve this problem, the participants mentioned that the government has two options:

\section{- Expansion of the production of the existing electricity plants}

The expansion of the production of the existing electricity generating plants in theory appears to be the most sensible strategy for the electricity company in the short-term. However, the power generating plants have been unable to meet the current demand. It appears that the mitigating strategy for energy organisations has been the rationing of electricity. While the improvement of the current power plants is likely to solve the electricity supply problem, it would be a short-term strategy that will soon be required to change.

\section{- Development of new power plants}

An alternative to the expansion of the existing power generation plants is the establishment of new plants in the future. As it has been established, electricity demand in Libya has been rising for decades as the economy has become more sophisticated. Therefore, it is easy to project the 
energy demands of the country in the next decade or more. In this regard, the new scalable power generation plants will have the capability to address the country's electricity needs both in the medium and long-terms.

Based on the revised framework, the government, energy firms and other stakeholders need to work together in order to get a long lasting solution to the electricity demand challenges. Consequently, an integrated approach is required to bring together the various stakeholders. The responsible parties are influenced by various factors. Population pressure, GDP, and household income are socio-economic factors which require socio-economic development policy. The government needs to carry out activities that will lead to socio-economic development. This could be economic reforms through planning, which takes into account the factors affecting the electricity industry, together with improved development of infrastructure in the other sectors of the economy.

\section{Conclusions and policy implications}

This study looked at the supply of electricity side in an attempt to explore the internal and external determinants of electricity projects and the impact of these determinants on electricity projects in Libya during the period from 1980 to 2010. As demonstrated in this study there are problems faced by both the government and industry practitioners. One of the problems identified was related to the dispersion of cities and rural as well as limited capital for the construction and maintenance of existing projects. There was ample evidence to suggest that the government of Libya has not constructed enough electricity projects to meet the level of electricity demand. Furthermore, the government of Libya has not adopted regular mechanisms to deal with the consistent upsurge in demand. 
As shown in this study, the problem can only be solved if the government manages to construct the proposed power plants in the country, and if the growing political fracture, growing militancy and minimal governance is addressed. The problem confronting development of electricity projects in Libya has three components: The first is the national significance of the projects as a physical resource. The second is the conflict arising politically from within. The third is the lack of consideration given to the specific resource management issues associated with the projects within the government plans and policy statements. In addition, participants further claimed that there were three more independent factors that could affect the level of electricity demand in Libya. These were urbanisation, industrialisation and literacy rates.

It was claimed by the participants that a rise in the degree of urbanisation in the last three decades is highly responsible for the increase in electricity demand in Libya. They claimed that an increase in the level of industrialisation in Libya has led to the soaring demand of electricity. This finding corroborates the ideas of Burns (1997), who suggested that the industry employs heavy machinery production processes that require a lot of electricity. The evidence from this study indicates that a rise in the level of literacy would generate a skilled professional workforce. Rising skills of the individuals would increase their income and also, the demand for electricity. In general, therefore, it seems that the electricity supply in the country is not enough to meet the demand for various activities that goes on in the country. Demand is high, which means the government has no option but to initiate more projects to deal with the issue of shortage. The discussions in this study confirm that the internal determinants of electricity projects in Libya are electricity demand and political effects. 
The external determinants are recession, oil prices and the development in other infrastructure. It was also shown that, the number of projects being initiated in Libya is mainly informed by the increased demand. With regards to factors that are affecting electricity production and consumption in Libya, participants rated highly population, followed by income. It is worth highlighting that the air embargo throughout the nineties and the administrative corruption and theft of the funds made it impossible for investors to carry out electricity production projects, renovation and maintenance of existing projects.

As observed in this study, the recession has had a minor impact on Libya's electricity projects, as they were ranked low among the factors affecting Libya's electricity projects. It is worth mentioning that, the impact of oil prices in the long run will represent the country's quest to convert many of the power plants from oil to natural gas. As shown in this study, the development of other infrastructure was the most effective factor of the external determinants. In addition, the deregulation of the economy at the beginning of the nineties led to the development of the commercial sector.

The findings from the framework have confirmed that the general electricity company in Libya and the Libyan government should consider incorporating the following actions:

- Economic planning;

- Socio-economic development policy;

- Development of new power plants and expansion of the existing capacity; and

- Improved development of other infrastructure.

The increased demand for electricity in Libya compels the government, the general electricity company and the other heavy engineering sectors to come up with a sustainable framework to meet the energy demands of the country. Despite the fact that the government has an option of 
expanding productivity of existing facilities, a better option would be to build new power projects. The two most significant factors to create maximum changes in the level of electricity demand in Libya are population and price. Reducing the level of population in a country is a far more elaborate and long process. However, the peaking demand for electricity in the market of Libya can be reduced by artificially manipulating its level of prices (increasing). It should be considered that this initiative would reduce the country's overall level of social welfare. The soaring demand for electricity in the country can only be sustained with the help of adequate supply. The existing government and stakeholders should take measures to address political unpredictability and raise the number of the electricity projects in the country.

These findings suggest several courses of action for the Libyan government. Firstly, there is the need to prioritise the construction programs (electricity projects) on the basis of benefits that can be derived from each project. It was found that a large proportion of individuals of the country live in the rural regions. The planning authorities should first execute the power generation projects that can provide services to the maximum number of individuals in the nation. Also, attracting foreign direct investments for new electricity projects in the country is necessary. For instance, many emerging economies in the world like China and Russia are found to be largely interested in investing money in business segments of other economies. Therefore, Libya should try to attract foreign investments from such nations to finance its power generation projects in its economy. The government of Libya must equally try to enhance its level of domestic and foreign investments for electricity projects. Efficient allocation of the resources is a method which would increase the electricity supply in the country in future. 


\section{References}

Al. Azzam, A. 2002. The Demand for Energy in Jordan. Unpublished PhD Thesis. University of Surrey.

Attiga, A., 1987. Oil and Arab Interests 1982-1987, first ed. Kuwait: Organization of Arab petroleum exporting. (in Arabic).

Barros, C.P., Gil-Alana, L.A., Payne, J.E., 2011. An analysis of oil production by OPEC countries: Persistence, breaks and outliers. J. Energy Policy. 39 (1), 442-453.

Bassam Fattouh, B., Darbouche, H., 2010. North African and foreign investment in changing market conditions. J. Energy Policy. 38 (2), 1119-1129.

Berndt, E. R. 1991. The Practice of Econometrics: Classic and Contemporary. Reading, Mass.: Addison-Wesley Pub. Co.

Bhattacharyya, S.C., Blake, A., 2009. Domestic demand for petroleum products in MENA countries. J. Energy Policy. 37 (4), 1552-1560.

Bhattacharyya, S.C., Blake, A., 2010. Analysis of oil export dependency of MENA countries: Drivers, trends and prospects. J.Energy Policy. 38 (2), 1098-1107.

Biresselioglu, M.E., Demir, M.H., Kandemir, C., 2012. Modeling Turkey's future LNG supply security strategy. J. Energy Policy. 46, 144-152.

Brand, B., 2013. Transmission topologies for the integration of renewable power into the electricity systems of North Africa. J. Energy Policy. 60, 155-166.

Bryman, A., Bell, E. 2011. Business Research Methods, third ed. Oxford University Press, Oxford, UK.

Bureau of Energy Data and Studies., 2004. LNEC-Libyan national energy information.

Chlebek, I., 1993. The Electric grid from the station to the consumer. Energy and life, the first issue, March, 14-17 (in Arabic).

Coudouel, A., Dani, A., and Paternostro, S., 2006. Poverty and social impact analysis of reforms lessons and examples from implementation. Washington DC, World Bank. Available from: http://public.eblib.com/EBLPublic/PublicView.do?ptilD=459404 [Accessed $19^{\text {th }}$ July 2015].

Creswell, J.W., 2014. Research Design. Qualitative, Quantitative and Mixed Methods Approaches, fourth ed. Sage Publications, California.

Daft, R.L., Marcic, D. 2013. Understanding Management. Australia: South-Western Cengage Learning.

Economic and Social Commission for Western Asia., 2007. International Migration and Development in the Arab region: challenges and opportunities. New York: United Nations. 
Ekhlat, M., Salah, I.M.,Kreama, N.M., 2007. Mediterranean and national strategies for sustainable development: Priority field action 2: Energy and climate change, energy efficiency and renewable energy, Energy and sustainable development in Libya. Plan Bleu, Regional Activity Centre: Sophia Antipolis.

Elabbar, M., 2008. The general electricity company of Libya: Power generation sector in Libya and strategic plan (GECOL). Damascus, 17 (6), 2-15.

Enerdata., 2013. Libya energy report, Energy Market Reports. Available at: https://estore. enerdata.net/ energy-market/ libya-energy-report-and-data.html.

Energy Market reports, 2012. Libya Energy Market Report. Available from: http://www.enerdata.net/enerdatauk/knowledge/eshop/energy-market-report/libya.php [Accessed $12^{\text {th }}$ February 2014].

Energy Department., 2013. Annual Energy Outlook with Projections: 2013 with Projections to 2040. Energy Information Admini.

Encyclopedia of the Nations., 2014. Libya Country Overview. Available from: http://www.nationsencyclopedia.com/economies/Africa/Libya.html [Accessed $9^{\text {th }}$ February 2014]

Espey, A., Espey, M., 2004. Turning on the lights: A meta-analysis of residential electricity demand elasticities. J of Agricultural and Applied Economics 36 (1), 65-81.

Firebaugh, G., 1992. Growth effects of foreign and domestic investment. American Journal of Sociology. 98 (1), 105-130.

Gelvin, J.L., 2012. The Arab Uprisings: What Everyone Needs to Know. Oxford University Press, New York.

Ghosh, S., 2009. Electricity supply, employment and real GDP in India: evidence from cointegration and Granger-causality tests. J. Energy Policy. 37 (8). 2926-2929.

Greene, W., 2008. Econometric Analysis, sixth ed. New York: Pearson Prentice Hall.

Guenos, S., 1999. Libya Revolution in Thirty Years: Political and Economic Transformations and Social 1969-1999, third ed. Misratah: The Libyan Publishing House, distribution and advertising (in Arabic).

General Electric Company. Annual Report., 2014. Tripoli: General Electric Company. Unpublished. (in Arabic).

General People's Committee for Planning., 1998. The Achievements of Economic and Social Development During the Twenty-Eight-Years, (April- 1998) (in Arabic). 
Halvorsen, R., 1993. Short-run Determinants of Residential Electricity Demand. Seattle: Institute for Economic Research, University of Washington.

Halvorsen, B., B. M. Larsen., B.M., 2001. The flexibility of household electricity demand over time. J. Resource and Energy Economics. 23 (1), 1-18

Lochner, S., Dieckhiner, C., 2012. Risks for natural gas supply? J. Energy Policy. 45, 167175.

Mason, M., Kumetat, D., 2011. At the crossroads: Energy futures for North Africa. J. Energy Policy. 39 (8), 4407-4410.

Marktanner, M., Salman, L., 2011. Economic and geopolitical dimensions of renewable vs nuclear in North Africa. J. Energy Policy. 39 (8), 4479-4489.

Mbendi., 2005. Electrical power in Libya- overview. Mbendi Information Services. Available from: http://www.mbendi.com/indy/powr/af/lb/p0005.htm. [Accessed 16 ${ }^{\text {th }}$ March 2014].

Mills, R. M., 2008. The Myth of the Oil Crisis: Overcoming the Challenges of Depletion, Geopolitics, and Global Warming. Westport, Conn, Praeger.

Momoh, J. A., and Mili, L., 2010. Economic Market Design and Planning for Electric Power Systems. Hoboken, N.J., Wiley.

Omran, A., 1993. Combined cycle: high efficiency to produce electricity and water desalination. J. Energy and Life. Vol. 1, 48-56. (in Arabic).

O'Sullivan., M. 2003. Shrewd sanctions; Statecraft and State Sponsors of Terrorism. Brookings Institution Press, Washington D. C.

Parker, P. M., 2011. The 2011 report on Autogenerated Electricity: The: World Market Segmentation by City. New York: M. Dekker.

Publishing, O., Agency, I. E. A., 2012. CO2 Emissions from Fuel Combustion 2012. Paris: Organisation for Economic Co-operation and Development.

Ramelli, O., Saleh, S., Stenflo, J. 2006. Prospects of Renewable Energy in Libya. International Symposium on Solar Physics and Solar Eclipses (SPSE) 2006. Tripoli, Libya.

Robbins, P. and Publications, Inc. (2007). Encyclopedia of Environment and Society. Thousand Oaks: Sage Publications.

Saleh, I., M., 2006. Prospects of renewable energy in Libya. International Symposium on Solar Physics and Solar Eclipses (SPSE) 2006, Vol. 1, 153-161.

Sehib,K., Jackson, E., Gorton, M. 2013. Gender, social acceptability and the adoption of supermarkets: evidence from Libya. J. Consumer Studies, 37 (4), 379-386. 
Shah, H., 1996. The production and use of natural gas in Libya. Oil and Arab Cooperation. 22 (78). 51-63, (in Arabic).

Siddiqi, A., Diaz Andon, L., 2011. The water-energy nexus in Middle East and North Africa. J. Energy Policy. 39 (8), 4529-4540.

Singh, S., 2010. Handbook of Business Practices and Growth in Emerging Markets. Hackensack. World Scientific.

U.S Energy Information Administration., 2013. Libya. Available from: http://www.eia.gov/countries/country-data.cfm?fips=LY [Accessed $16^{\text {th }}$ June 2014]

USA, I., 2007. Arab fund for Economic and Social Development Handbook. International Business Publications. Washington, DC.

Willis, K., 2011. Theories and Practices of Development, second ed. Abingdon, Oxon, Routledge.

World Atlas (2014). World map Libya. Available from:

http://www.worldatlas.com/webimage/countrys/africa/lgcolor/lycolor.htm [Accessed 14th March $\underline{2014]}$

World Bank., 2012. Rethinking the Role of the State in Finance. Washington, DC: World Bank.

Zoubir, Y., 1999. North Africa in Transition: State, Society, and Economic Transition in the 1990s. University Press of Florida, Florida. 